\title{
4-1994
}

\section{Politics and Systemic Education Reform}

Susan H. Fuhrman

University of Pennsylvania, susanf@gse.upenn.edu

Follow this and additional works at: https://repository.upenn.edu/cpre_policybriefs

Part of the Education Policy Commons

\section{Recommended Citation}

Fuhrman, Susan H.. (1994). Politics and Systemic Education Reform. CPRE Policy Briefs.

Retrieved from https://repository.upenn.edu/cpre_policybriefs/68

View on the CPRE website.

This paper is posted at ScholarlyCommons. https://repository.upenn.edu/cpre_policybriefs/68

For more information, please contact repository@pobox.upenn.edu. 


\section{Politics and Systemic Education Reform}

Abstract

This brief describes political challenges to systemic reform and explores the condition under which coherent policy-making might occur.

Disciplines

Education Policy

Comments

View on the CPRE website. 


\title{
Politics and Systemic Education Reform
}

\author{
by Susan Fuhrman
}

As many as 45 states are involved in a reform movement focusing on ambitious student standards, coordinated policies and support for school-level change. This has been labelled "systemic reform" (e.g., Smith and O’Day 1991). But the idea is greeted by many political observers with skepticism. How can we expect such a rational approach-definition of student learning expectations and the purposeful integration of key policies-from a system that has long made policies incrementally and in a disjointed fashion? (See Lindblom 1959; Wildavsky 1974.)

While many obstacles to systemic reform do exist, some promising efforts indicate that policymakers can enact ambitious goals and support them with coherent, coordinated policies. This brief describes political challenges to systemic reform and explores the conditions under which coherent policymaking might occur. It includes excerpts from "The Politics of Coherence," in Fuhrman, ed. Designing Coherent Education Policy: Improving the System (San Francisco: Jossey-Bass 1993). It also draws on two background cases of political structures designed to support education reform: "South Carolina's Business-Education Subcommittee" by Diane Massell and "Kentucky's Prichard Committee" by Jacob Adams.

\section{Political Challenges Facing Systemic School Reform}

The concept of systemic school reform, as used in this brief, focuses on the establishment of ambitious expectations for all students. Standards would be set at a high-level, requiring deep understanding of subject matter and sophisticated reasoning ability. Curriculum frameworks laying out important topics and understandings would be the foundation for student assessment, instructional materials, teacher licensing and staff development. In that manner, key policies would send coherent messages about instruction (Cohen and Spillane 1993).

The purpose of a more coherent policy system would be to support and sustain school-based change. To provide schools more flexibility in meeting the needs of their students, higher levels of governance would focus on defining and developing accountability for results and would remove constraints on school practice. Schools would determine the instructional strategies most likely to foster student achievement of outcome goals (Smith and O'Day 1991; CPRE 1991).

All levels of governance-local school districts, states and the federal government-might work to define standards and coordinate key policy instruments. Many districts and states are already making such efforts. And, with the active support of the Clinton Administration, voluntary national standards are

Susan H. Fuhrman is professor of educational theory, policy and administration at Rutgers, The State University of New Jersey. She also serves as director of the Consortium for Policy Research in Education.

Dr. Fuhrman is the author of numerous articles, research reports and monographs on education policy and finance. Dr. Fuhrman was a consultant to the Ford Foundation's program on educational management and finance for 10 years and served as vice-president of the school board in Westfield, New Jersey.

\section{CONSORTIUM FOR POLICY RESEARCH IN EDUCATION}

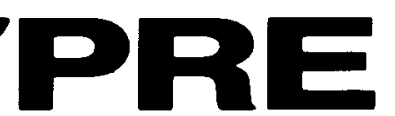

Rutgers, The State University of New Jersey

University of Wisconsin-Madison. Harvard University

Stanford University - University of Michigan 
being developed in key subjects. Considerations about the politics of systemic reform are therefore relevant to several levels of government. However, this brief focuses primarily on the role of states, since they have both constitutional responsibility for education and the jurisdiction over both pre-collegiate and higher education necessary to achieve policy integration. Conceptions of systemic reform include two important ideas: societal decision about student standards and coordination of important policy instruments. Yet these ideas face several challenges.

\section{Student Standards}

The systemic reform strategy suggests that a decision be made about challenging core expectations for student learning. Right now schools and districts often defer to textbook publishers' Tables of Contents for decisions about which topics to include in curricula and let standardized testing define the skills chidren should learn. Often, neither texts nor tests encourage a focus on high-level skills (Tyson Bernstein 1988; Archbald and Newmann 1988). In fact, in the absence of explicit consensus about outcomes, the system puts a de facto emphasis on low-level skills which are familiar and relatively easy to teach.

Furthermore, because clear direction is lacking, the system has no authentic means of judging its progress and no substantive base for resource allocation decisions (Odden 1991). Formulas or traditional expenditure patterns typically drive the allocation of spending increases and cuts. Resources are seldom distributed based on explicit decisions about how money should be used. The system has not yet determined how to use resources effectively in part because the system has yet to determine the outcomes to be effectively achieved (Odden and Massy 1992).

Policymakers have avoided central-for example, state-leveldetermination of outcome expectations by summoning up the hallowed educational tradition of local control. In fact, deep conflicts over the purposes of education have made policymakers wary of opening goal discussions (Tyack 1976; 1992). In our increasingly diverse society, there are many differences of opinion about what should constitute a core body of content learned by all students. By letting content expectations devolve to the district or school, policymakers can evade such difficult decisions. Furthermore, if, as some analysts assert, society's interest in education lies primarily in credentialling in a way that preserves economic and social inequities, there is little reason to bother with content expectations. Others argue that because knowledge is constructed by individuals in specific contexts, it would be counterproductive to specify knowledge expectations for an entire society, no matter how worthy the expectations.

In the past, educators rarely challenged the status quo-the absence of policy-level outcome expectations. In fact, many have argued strongly against this type of "policy interference" (e.g., Wise 1979; McNeil 1986). For one thing, they were highly skeptical that policymakers could develop standards that were ambitious and challenging with respect to student achievement. Politically determined standards are typically not challenging; rather they tend to be minimal in nature. And, in the absence of consensus about results, standards focus on inputs and processess. These can be criticized for constraining professional judgement and necessary school flexibility.

\section{Coordinated Policies}

The systemic reform strategy also proposes that a series of key policies should be aligned with outcome expectations. It suggests departing from the current practice of fashioning a separate program to address each educational problem because the individual projects, no matter how uniquely worthy, seldom reinforce one another and frequently send different, even conflicting, messages to schools. For example, most current teacher certification and evaluation requirements stress generic skills rather than ability to teach the subject-matter content students must know. Programs for students with special needs pull them away from the mainstream curriculum, fragmenting not only their education, but the work of teachers and administrators. Staff development frequently consists of one-shot workshops on "hot" topics that are unrelated to each other or to the fundamental instructional and pedagogical issues teachers face daily.

The rationality of integrated policy based on deliberate goals is at once the appeal and the Achilles' heel of systemic reform. Consensual decision and policy coordination have seemed beyond the capacity of our political system. In fact, it is arguable that our political system functions so as to deliberately thwart decisiveness and coordination.

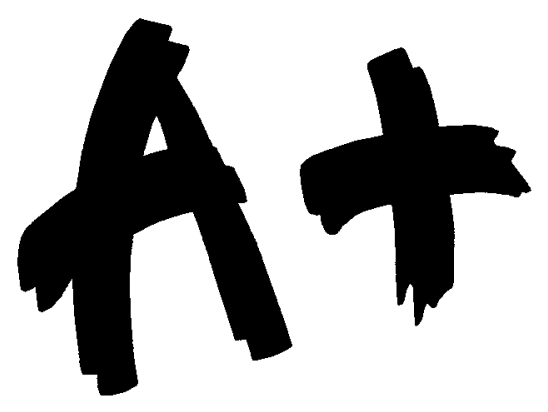




\section{Impediments to Consensus and Coordination}

At least four characteristics of the political system contribute to incoherent policymaking: the fragmented organizational structure; the focus on elections; policy overload; and specialization.

\section{Fragmented System}

First, the fragmentation of our political system makes it very difficult for policymakers to coordinate with one another or to develop consensus across all parts. Separate branches of government that check and balance one another exist at each level of government. Each part operates according to its own schedules and rules, its members swayed by incentives related to institutional membership and maintenance rather than the functioning of the entire system. Opportunities to work with policymakers in other institutions do not naturally occur or may require facilitation through the creation of new institutions, further increasing the structural complexity of government.

Educational governance is particularly complex (Cohen 1982). Not only are there three levels of government (federal, state and local) making education policy, but also there are separate structures (e.g., state boards of education) at each level that date from the Progressive era emphasis on isolating education from partisan politics.

\section{Focus on Elections}

A second characteristic of our system that thwarts rational policymaking is the emphasis placed on campaigning and election. The "electoral connection," a priority on re-election above policy or institutional improve- ment goals, is probably most apparent in Congress where livelihood and career depends on staying in. However, as state legislatures become more fulltime, and thus more composed of career politicians, "the permanent campaign" is also becoming more characteristic of most state houses (Salmore and Salmore 1990; Rosenthal 1989). Executive branch elected officials face similar imperatives.

Because impressions on constituents take priority, politicians seek ways to distinguish themselves from their colleagues rather than avenues to cooperate in group decisions. They deal in what Mayhew (1974, 54-59) calls "particularized benefits," porkbarrel projects or other "goodies" which particularly help their own constitutencies and are clearly traceable to their originators. They fashion unique, discrete, "sexy" policies to which they can attach their name.

A second consequence of the preeminence of elections is the circumvention of controversial and difficult issues which can upset elements of the electorate. Finally, because of the emphasis on election, politicians are attracted to the type of policies that are most easily used as campaign issues: simple, easily explained policies that can be featured in a "sound bite." Policies with immediate effects and clear benefits are simpler to explain than longer term efforts with more diverse or remote benefits. Subtlety can lose out to flashiness; careful developmental efforts can lose out to quick pushes that have less chance of success because the developmental groundwork was lacking.

\section{Policy Overload}

A third characteristic of the system that thwarts coordination is an overload with policy issues.
Over the last decade most states made policy on a number of important education issues-like teacher salaries or the nature of student assessment-for the first time. These subjects had generally been left to local educators in the past. But, although states expanded their policy purview, local districts did not constrict their own activities in response. Local districts made more policy as well (Fuhrman and Elmore 1990). When so much is on the plate, each item can get less attention. And, the sheer volume increases the likelihood that policies will tumble out, without any necessary connection to a long-range strategy or to one another.

\section{Specialization}

A traditional strategy for managing the complexity that comes with too much work is specialization. It reflects not only the expansion of the governmental role but also the emphasis on election. Specialization creates more arenas in which politicians can claim credit and impress voters. Consequently legislative committees and subcommittees multiply and narrow their jurisdictions; special boards and commissions are created; new agencies are established. For example, in 16 states, at least one legislative chamber has separate committees for higher education and for elementary and secondary education. In 5 of those states, each house has separate committees for the levels of education.

However, specialization contributes to the fragmentation of the system. Policies are crafted by experts with increasingly narrow perspectives and experts in a particular sub-field have few incentives to consider how their actions will affect other specialized sub-fields. While bills often contain multiple provisions crossing many sub-areas of policy, they 
are typically omnibus in nature, containing collections of discrete programs rather than integrated approaches to policy problems.

\section{Opportunities for More Coherent Policymaking}

Despite the serious challenges facing systemic reform, recent activities in a number of states suggest that policymakers can establish ambitious goals and reinforce them with coordinated policies. Certain factors and conditions seem to support these efforts.

Pending further study of the politics of reform efforts, it appears that the following are central to the development of systemic reform strategies: strong leadership around a clear vision of reform; processes that promote public and professional involvement; and the support of the federal government, national groups and professional and policymaker associations.

Leadership can come from a variety of sources. For example, the Kentucky legislature can be credited with enacting, and sticking with, the state's ambitious reform; in some states, such as Delaware and Vermont, the chief state school officers are providing strong direction. Governors Romer and Engler are among those actively shaping reform efforts.

Public and professional involvement can be promoted by standards-setting processes that involve citizens and professionals in various stages of standards development and review. Broader support can nuture and buffer fragile political efforts that try to bridge traditional divisions and overcome short-term blinders in service of coherent policymaking.

Finally, the federal government and national associations of policymakers and professionals are actively promoting systemic reform, helping to reinforce the commitment of state policymakers. The federal government assists states with systemic reform through efforts like the National Science Foundation's Statewide Systemic Initiatives Program. It also supports disciplinary associations that are developing national standards in key subjects that can be used by states in their own reforms. Groups such as the National Governors' Association, the Council of Chief State School Officers, the National Conference of State Legislatures, and the Education Commission of the States assist policymakers with the difficult design and implementation tasks associated with reform. They also validate the work of policymakers within their states by giving them national publicity and reinforcement (Fuhrman and Massell 1992; Massell 1994; Massell and Fuhrman 1994; Massell and Kirst 1994; Fuhrman and Elmore 1994).

An interesting development is the willingness of state policymakers to experiment with new structures, such as long-term commissions which in turn offer avenues for the maintainence of coherent reform over time. They address the problems of fragmentation, overemphasis on election, policy overload and specialization by uniting representatives across fragmented policy arenas and outliving changes in political leadership. Such structures promote consensus on a reform agenda that mitigates against political tendencies to veer off in new directions.
Two entities that are frequently cited-Kentucky's Prichard Committee and the South Carolina Business-Education Subcommittee-are profiled in the sidebar on page 5 . These bodies, the first a volunteer citizen's organization with almost 100 members and the second a 20-member leadership group with statutory reformrelated authority, illustrate how such structures can work to support reform. They perform at least five important functions that grant them great influence in shaping and sustaining reform efforts.

\section{Both the Prichard Committee and the Business-Education Sub- committee represent a variety of constituencies.}

This enables them to provide effective advocacy for reform and to link diverse interests. Because their memberships bridge institutions, levels of governance, political parties, and the private and public sectors, they are viewed as credible voices for children. They are not driven by electoral politics nor are they responsive to narrow constituencies.

Early success in mobilizing citizen participation and support for reform helped establish the "voice of the people" reputations of both groups. In 1984, shortly after it incorporated as a private, nonprofit citizens group, the Prichard Committee organized a televised statewide town forum which involved 20,000 Kentuckyians and contributed to the governor's call for a special legislative session on education. The SC Subcommittee is a joint working committee of two larger groups formed in 1983 by then Governor Richard Riley; their efforts to generate broad-based grassroots support led to the Education Improvement Act (EIA) of 1984, 
an accompanying sales tax increase, and a network of 26,000 people who can still be called on to support education.

* Second, both groups are mechanisms for the incorporation of business interests into larger reform coalitions.

Prior to EIA, business had never before rallied to support an increase in the sales tax for education in South Carolina. In the years since, the Subcommittee has been a strong voice for maintaining the state's financial commitment to reform. A few years ago, the Prichard Committee formed the Partnership for Kentucky School Reform with the state Business Roundtable specifically to "maintain solidarity for the implementation of the Kentucky Education Reform Act (KERA)" (Prichard Committee 1992, 6). The Partnership was launched with $\$ 1.5$ million from key Kentucky corporations.

In these states, unlike others, there is no doubt that business supports education, no separate "business" agendas, no concerns that business leaders pursue policy intiatives primarily because they distrust educators and want them controlled. Instead business leaders are key participants in crafting, negotiating, supporting, selling and sustaining reform efforts. Their inclusion widens reform support and helps to buffer reforms from the vagaries of political change.

\section{Third, Prichard and the Subcommittee serve as training grounds for leader- ship, both within education and more generally.}

The current governor and lieutenant governor of Kentucky are former Prichard members; its membership list is frequently used by officials seeking nomi-

\section{Citizens Unite to Support Reform}

\section{The Prichard Committee for Academic Excellence}

This is a non-profit, volunteer group composed of 95 private citizens, including former governors, buisness leaders, civic activists, parents and professionals. Membership is not open to statewide elected officeholders or candidates or professional educators (except K-12 classroom teachers).

Prichard began as a governmental committee charged with studying the longterm needs of postsecondary education. In 1983 it became a private, nonprofit organization and turned its focus to $\mathrm{K}-12$ education. It developed reform recommendations, publishing major reports demonstrating the need for reform, arguing for coordinated reform policies and suggesting specific reform approaches; organized citizen and business support; and assisted the legal and political processes that spawned the 1990 Kentucky Education Reform Act (KERA).

Currently, the Committee monitors and supports reform implementation. With funding from corporations and foundations and a staff of 17 people, the Committee is pursuing the following activities:

- Informing the general public about provisions of the reform act and its implementation through summmaries, reports, the media, primers, training of local affiliates and the like.

- Enlisting, training and supporting citizens through Community Committees on Educational Reform. Community Committees in each district are intended to inform the public, recruit and train school site council candidates, develop local leadership and monitor local implementation progress.

- Promoting and supporting parent participation in school-based decision making through training and information.

- Monitoring, evaluating and reporting state progress on KERA. Activities include training Committee members and other affiliates for monitoring tasks, creating a state-level checklist of implementation activities, publicizing open meetings, and supporting and disseminating studies of reform. Prichard plans annual reports to the state on implementation progress.

- Reporting to the nation on KERA progress, through dissemination and media relations.

\section{The South Carolina Business-Education Subcommittee}

This is a joint subcommittee of two large blue-ribbon committees which were active in promoting the 1984 Education Improvement Act (EIA). EIA authorized the Subcommittee and charged it with reviewing program regulations to assure conformity to EIA; reviewing evaluations and assessments of progress produced by the state agency and other oversight bodies; and making recommendations for the future. Recommendations are to encompass educational needs in the state and current reform policies needing updating.

The 20 -member Subcommittee ( 10 civic/business members; 6 educators and 4 legislators, by statute) has a small staff and appropriation. It produces an annual report evaluating EIA progress and widely distributes shorter updates. The reports draw on other monitoring and evaluation activities as well as the Subcommittee's own sense of issues requiring attention, needs for finetuning and recommendations for improvement.

nees for boards, commissions and the like. Several long-term citizen members of the SC Subcommittee have become key participants in diverse education-related activities throughout the state.
Members take commitment to reform along with them to their new activities and responsibilities, enhancing the likelihood that reform direction will be sustained over time and supported by an 
ever-broadening group of influentials.

\section{Fourth, the reporting and monitoring functions of these groups, keep public attention focused on reform.}

Both groups regularly inform citizens about implementation progress and effects and continually remind them that the reforms will take time to bear full fruit.

Faithful implementation is encouraged by regular reporting on progress. Policymakers have means other than new policy initiatives to show their dedication to education improvement; they can participate in the activities of these groups and comment on their reports of reform progress. As a consequence, these states are likely to experience fewer shifts in emphasis and less proliferation of projects. Reform direction is more likely to be maintained over time. For example, the EIA remained intact while the Subcommittee examined its progress yearly; many of the Subcommittee'srecommendations for fine-tuning were then incorporated into the 1989 Target 2000 reform. Because oversight was occurring, the later reform was deliberately built on and designed to improve the first, not developed in the absence of knowledge about the effectiveness of existing policy, as many reforms are.

\section{St Finally, both groups are vehicles for sharing state reform efforts with a multi-state audience and for channelling national expertise to state policymakers.}

The Prichard Committee has a national advisory panel to guide it in establishing monitoring priorities and to offer advice regarding best practice in key reform areas. It disseminates information about media and audiences. It also convened a meeting of national researchers and participated in designing an independent evaluation of KERA. Similarly, the SC Subcommittee's EIA Update has reached a wide audience, and South Carolina reform has received extensive national media coverage. The national reinforcement helps cement in-state support for reform.

The success of the Prichard and South Carolina committees is evident in their influence. Both have served to generate ideas that have been incorporated into policy; the Kentucky Education Reform Act (KERA) and Target 2000 include many of their recommendations. More informally, their members serve as sounding boards for policymakers.

The groups do not go unchallenged, however. Prichard is not uniformly lauded by practitioners and has been at odds with the school boards association over the roles of school-site councils. To smooth these relationships, the Committee participates in an Education Coalition of major state education organizations designed to present a unified position on education legislation. The Business-Education Subcommittee is currently experiencing some instability related to shifts in its leadership and to an increasingly complex and partisan political environment, suggesting efforts to bridge changes in leadership are problematic. In addition, both the Kentucky and South Carolina groups raise questions about whether new consensus-building structuresformal or volunteer-facilitate the work of existing structures or become routes for bypassing or duplicating their work. As Morone (1990) argues, such entities can make government temporarily more responsive; but over time they may add to rather than lessen the complexity and impenetrability of the policy process.

Despite these questions, the Prichard Committee and the Business-EducationSubcommittee provide many lessons about the role of constituency-bridging groups in building and sustaining support for reform. In at least six other states, non-profit organizations located outside of state bureaucracy are taking the lead for reforms supported by the National Science Foundation's Statewide Systemic Initiatives Program. Participants indicate that locating leadership in a new organization permits broader participation, unites diverse interests, avoids red tape, and enables them to hire staff at higher salaries than offered by state government (Corcoran 1993).

\section{Conclusion}

Because the political system seems incapable of coherent approaches and sustained direction, many argue that politics should be abandoned altogether-by subjecting schools to market control or by removing policies so that schools can improve themselves unfettered.

However, the abandonment of policy does not offer hope of widespread improvement because schools are not able to sustain self-generated change. Nor is school-by-school change likely to spread to all schools. The system must offer support. Current systemic reform efforts suggest that states are willing to experiment with more coherent approaches to policy that might offer support for school improvement. Perhaps systemic reform's recent popularity reflects its political appeal as a basis for unifying those interested in edu- 
cational improvement. The notions of more ambitious standards, coherent policy in support of those standards, and restructured governance reach across traditional lines of division, providing a platform for unification. The idea that higher-level policy should focus on results rather than school process appeals both to policymakers concerned about accountability and to practitioners who want to keep policymakers out of decisions about their practice.

Similarly, the idea that consensus about results should focus on a streamlined core body of knowledge and skills attracts educators who wish to leave determination of detailed curricula to the school and foster the ability of schools to meet the needs of diverse student bodies. State curriculum frameworks and reinforcing policies could provide a protective structure that would undergird strategies for parental choice and other approaches to decentralizing school governance. To the extent that systemic reform ideas form a platform for uniting diverse reform constituencies they take on political power.

The ideas that exert the greatest influence are those that balance political forces, finding ways to enlist existing interests as well as to open up new opportunities. Systemic reform has many of the properties of so-called "public ideas" (Moore 1988; Reich 1988). It challenges "society to perceive and deal with a problem differently" (Moore 1988, 83) by changing the terms of the education reform debate. The new entities states are establishing as arenas for reform discussion illustrate that constituency-bridging ideas and structures may go hand in hand.

\section{References}

Archbald, D. A., and F. Newmann. 1988. Beyond StandardizedTesting: Assessing Authentic Academic Achievement in the Secondary School. Reston, VA: National Association of Secondary School Principals.

Cohen, D., and J. Spillane. 1993. "Policy and Practice: The Relations Between Governance and Instruction." In S. Fuhrman (ed.), Designing Coherent Education Policy: Improving the System. San Francisco: Jossey-Bass.

Cohen, D. K. 1982. "Policy and Organization: The Impact of State and Federal Educational Policy on School Governance." Harvard Educational Review, 52(4): 474-499.

Consortium for Policy Research in Education. 1991. "Putting the Pieces Together: Systemic School Reform." CPRE Policy Briefs. New Brunswick, NJ: Author.

Corcoran, T. 1993. "Building Capacity for Systemic Reform: New Agendas, New Structures." Paper prepared for APPAM Conference, October 1993.

Fuhrman S. and D. Massell. 1992. Issues and Strategies in Systemic Reform. New Brunswick, NJ: Consortium for Policy Research in Education, Eagleton Institute of Politics, Rutgers University.

Fuhrman S. and R. Elmore. 1990. Understanding Local Control in the Wake of State Education Reform. Educational Evaluation and Policy Analysis, 12(1): 82-96.

Fuhrman, S. H., and R. F. Elmore. 1994. "Governors and Education Policy in the 1990s." In S. H. Fuhrman and R. Elmore (eds.), The Governance of Curriculum. Washington, DC: Association for Supervision and Curriculum Development.

Lindblom, C. 1959. "The Science of Muddling Through." Public Administrative Review, 19(2), 79-88.

Massell, D. and S. Fuhrman (with M. Kirst, A. Odden, P. Wohlstetter, R. Carver, G. Yee). 1994. Ten Years of State Education Reform: Overview with Four Case Studies. New Brunswick: Consortium for Policy Research in Education, Eagleton Institute of Politics, Rutgers University.

Massell, D. 1994. "Achieving Consensus: Setting the Agenda for StateCurriculum Reform." In S. H. Fuhrman and R. Elmore (eds.), The Governance of Curriculum. Washington, DC: Association for Supervision and Curriculum Development.

Massell, D., and M. W. Kirst (eds.). 1994. Education and Urban Society, 26(2). Entire issue is devoted to Setting National Content Standards.
Mayhew, D. 1974. Congress: The Electoral Connection. New Haven, CT: Yale University Press.

McNeil, L. 1986. Contradictions of Control. New York: Routledge \& Kegan Paul.

Moore, M. 1988. "What Makes Public Ideas Powerful?" In Robert Reich (ed.), The Power of Public Ideas (pp.55-82). Cambridge, MA: Ballinger.

Morone, J. A. 1990. The Democratic Wish. New York: Basic Books, Inc.

Odden, A. 1991. School Finance in the 1990s. Phi Delta Kappan, 73(6): 455461.

Odden, A., and W. Massy. 1992. Funding Schools and Universities: Improving Productivity and Equity. New Brunswick, NJ: Consortium for Policy Research in Education, Eagleton Institute of Politics, Rutgers University.

Prichard Committee for Academic Excellence. 1992. Annual Report: January-December 1991. Lexington, KY: Author.

Reich, R. (ed.). 1988. The Power of Public Ideas. Cambridge, MA: Ballinger.

Rosenthal, A. 1989. "The Legislative Institution: Transformed and At Risk." In Carl Van Horn (ed.), The State of the States (pp.69-103). Washington, DC: Congressional Quarterly Press.

Salmore, S., and B. Salmore. 1990. Campaigns and Elections and the Legislature. A paper prepared for the Eagleton Institute of Politics for the Symposium on the Legislature in the Twenty-First Century, Williamsburg, Virginia, April 1990.

Smith, M. S. and J. O'Day. 1991. "Systemic School Reform." In S. Fuhrman and B. Malen, (eds.), The Politics of Curriculum and Testing. Philadelphia, PA: Falmer Press.

Tyack, D. 1976. "Ways of Seeing: An Essay on the History of Compulsory Schooling." Harvard Educational Review, 46(3): 355-89.

Tyack, D. 1992. "Public School Reform: Policy Talk and Institutional Practice." American Journal of Education, 100(1): 1-19.

Tyson-Bernstein, H. 1988. "The Academy's Contribution to the Impoverishment of America's Textbooks." Phi Delta Kappan, 70(3): 193-98.

Wildavsky, A. 1974. The Politics of the Budgetary Process. Boston: Little, Brown.

Wise, A. 1979. Legislated Learning. Berkeley: University of California Press. 